\title{
Famílias palestinas no extremo sul do Brasil e na diáspora: experiências identitárias e aduaneiras*
}

\author{
Denise Fagundes Jardim**
}

\begin{abstract}
Resumo
Nos parágrafos a seguir, para refletir sobre temas como a "identidade palestina" ou "a família árabe", tentarei demonstrar, a partir do estudo etnográfico de famílias morando em Chuí, o quanto a identidade territorial tem a ver com aspectos da vida familiar. Entre viagens de retorno (que introduzem jovens "brasileiros" no convívio com primos, tios e tias na Palestina), relações familiares (na diáspora, vínculos travados na cidade de Chuí e outras localidades no Brasil e no exterior), e acontecimentos internacionais recentes -- não será uma única explicação que dará a entender a recriação e a pertinência de uma identidade social calcada no reconhecimento de uma origem e um destino comum.
\end{abstract}

Palavras-chave: Família, Migrações, Diáspora, Nacionalidade, Palestinos, Identidade Étnica.

\footnotetext{
* Recebido para publicação em maio de 2007, aceito em agosto de 2007.

** Antropóloga, Departamento de Antropologia e do PPGAS da Universidade Federal do Rio Grande do Sul. dfjardim@portoweb.com.br
} 
Famílias palestinas no extremo sul do Brasil e na diáspora

Palestinian Families in the Extreme South of Brazil and in the Diaspora: Experiences of Border-Crossing and Identity

\begin{abstract}
In the following paragraphs, to investigate themes such as "Palestinian identity" or "the Arab family", and drawing on an ethnographic study of families living in Chui, I intend to demonstrate the extent to which territorial identity is intermingled with aspects of family life. Between "return trips" (that introduce young Brazilians to the daily life of cousins, aunts and uncles in Palestine), family relations (in the diaspora, relations forged in the city of Chui and other places in Brazil and abroad), and recent international events - there is no single element that can explain the re-creation and the relevance of a social identity based on the recognition of a common origin and destiny.
\end{abstract}

Key Words: Family, Migrations, Diaspora, Nationality, Palestinians, Ethnic Identity. 
Em 1996, quando iniciei meu trabalho de campo no Chuí ${ }^{1}$, algumas das informações coletadas levavam-me a perguntar por que nos anos 80 e 90 certas atividades coletivas e lúdicas traçavam a idéia de uma presença massiva na localidade de uma "comunidade árabe" e, especificamente, palestina. Faziam parte das iniciativas coletivas: a "Sociedade Árabe Palestina Brasileira Beneficente" (conhecida como o "clube árabe"), o "Central Palestino" (um time de futebol que competira nas eliminatórias do departamento de Rocha visando o campeonato nacional uruguaio) e as "festas de casamento", em trajes trazidos da Palestina. Além dessas atividades sociais, lúdicas e públicas no Chuí e Santa Vitória do Palmar, produziram monumentos, nomes de ruas e desfiles em comemoração ao "Dia da Terra" (30 de março) tomado do calendário político da militância da Organização da Liberação de Palestina (OLP). Tratava-se de símbolos que movimentavam pessoas acerca da origem árabe $e$ faziam circular eventos e documentos sobre a presença de palestinos na localidade. Era patente que acontecimentos internacionais se refletiam e revitalizavam a vida local. Meu objetivo original era entender como se processava a mistura de identidade, território e família.

Para refletir sobre temas como a "Identidade Palestina" ou "a família árabe" a partir do estudo etnográfico de famílias morando no Chuí, é necessário reconhecer que se tratam de noções historicamente construídas, sujeitas a negociações diversas. Nos parágrafos a seguir, tentarei demonstrar o quanto a

${ }^{1}$ O Chuí é uma localidade situada na fronteira com o Uruguai no extremo sul do Brasil a cerca de $500 \mathrm{~km}$ de Porto Alegre e 20km de Santa Vitória do Palmar pela $\mathrm{Br} 471$, e a $340 \mathrm{~km}$ de Montevidéu pela Ruta 9. Trata-se, de fato, de duas cidades contíguas em seu espaço urbano - Chuy e Chuí -, localizadas em um estreito trecho de terra entre o mar e a lagoa Mirim. O núcleo urbano das duas cidades está entre as aduanas internacionais, os países são "separados" apenas por duas avenidas de mão dupla (a avenida Brasil e avenida Uruguai) que acompanham boa parte do trecho de terra da área limítrofe entre Uruguai e Brasil. 
Famílias palestinas no extremo sul do Brasil e na diáspora

identidade territorial tem a ver com aspectos da vida familiar, de viagens intercontinentais $e$ visitas que introduzem jovens "brasileiros" no convívio com primos, tios e tias na Palestina ou outras localidades. Ao colocar a ênfase na migração e na diáspora, estarei fitando as experiências identitárias dos "entre-lugares" da vida familiar, seguindo a recomendação de autores como Homi Bhabha (1998) e James Clifford (1997) de atentar para os significados dos trânsitos e não exigir das imigrações contemporâneas com compromissos e projetos de alocação previamente projetados e previstos pelos sujeitos que imigram.

Entretanto, como introdução, cabe lembrar que a migração é um processo que requer não só condições financeiras, mas um cálculo mais amplo sobre as possibilidades de permanência legal. A "Autoridade Palestina" desde 1968 tem uma ampla definição do que venha a ser palestino. De acordo com a Carta Nacional Palestina de Julho de 1968 são palestinos todos aqueles de nacionalidade árabe que, até 1947, residiam normalmente na Palestina. Inclui tanto os que foram expulsos dela quanto os que lá permaneceram. Qualquer um que tenha pai palestino - dentro ou fora da Palestina - é também palestino. São palestinos também os judeus que residiam na Palestina antes do início da invasão sionista, cuja data é bastante imprecisa (ou 1917 com a Declaração de Balfour, ou 1947 em plena guerra ou ainda em maio de 1948 com a proclamação do Estado de Israel). O reconhecimento dos palestinos nas vias diplomáticos internacionais significou a instauração de escritórios de representação política em vários países a fim de que os evadidos em 1948 pudessem ser reincorporados. Ações como esta visavam não só inseri-los nas práticas políticas da OLP, mas também ampliar a divulgação internacional que dá suporte $e$ reconhecimento internacional para a "causa Palestina" $e$ a existência de um "povo palestino".

Entretanto, a situação de partida de meus entrevistados não se ajusta a uma versão genérica de "refugiados". A identidade palestina, como pretendemos mostrar, tem um tortuoso e múltiplo 
caminho. É uma autodenominação que não é produzida unicamente pela experiência dos migrantes que encontro no Chuí. Sua recriação, como veremos, acaba retomando temas importantes como a competência lingüística, a aldeia de origem e a "família árabe".

O reconhecimento do Estado Palestino pela ONU na década de 80 significou a produção de diversas atividades coletivas no Chuí. Todavia, deve-se entender os meandros da denominação de palestino em seus vários planos. Mesmo antes dessa inserção da OLP, algumas famílias tinham esboçado tentativas de voltar a morar na Palestina no início dos anos 80. Para isto, utilizavam seus passaportes brasileiros, obtidos depois de vinte anos de permanência no Brasil. Outros imigrantes, usando variados arranjos familiares, tinham encaminhado os filhos em idade escolar para estudar na cidade de Ramallah, mesmo que se mantivessem em suas atividades no Chuí, o que significava temporadas de afastamento entre pais $e$ filhos ou de parte da família residir por temporadas "aqui" e depois "lá". Assim, esperamos demonstrar que - entre viagens de retorno a Palestina, relações familiares (entre a diáspora e vínculos travados na cidade do Chuí e outras localidades no Brasil e no exterior), e acontecimentos internacionais recentes - não será uma única explicação que dará a entender a recriação e a pertinência de uma identidade social calcada no reconhecimento de uma origem e um destino comum.

\section{A pesquisa de campo: o Chuí revisitado}

Este artigo é parte de um estudo sobre a experiência migratória de famílias de origem árabe cuja entrada no Brasil data do final dos anos 50. Trato das famílias que se instalaram na cidade do Chuí no final dos anos 60 embora mantenham familiares em Santa Vitória do Palmar, Pelotas, Rio Grande, entre outras cidades no interior do Rio Grande do Sul e no exterior. São famílias que explicitam os laços que detêm fora do Brasil, se 
Famílias palestinas no extremo sul do Brasil e na diáspora

referem aos filhos estudando na Palestina, ou que fizeram boa parte de sua escolarização no exterior, no Canadá, Inglaterra, Estados Unidos e Argentina. Essas famílias proporcionam aos jovens filhos uma experiência singular de trânsito internacional com a finalidade seja de investimento escolar, seja de estreitar os vínculos entre familiares. Para tanto, realizam visitas periódicas, viajam para participar de festas, sobretudo os noivados $e$ casamentos. Essas viagens se tornaram uma das formas de viabilizar uma educação informal "de acordo com seus costumes". Imigrantes de origem árabe ou Palestina são encontrados em diversas cidades no interior de todo o Rio Grande do Sul. A escolha da localidade do Chuí como campo de pesquisa ocorreu não só pela viabilidade de acompanhar uma grande concentração de migrantes que se instalam em lojas lado a lado, estendendo-se na avenida internacional ${ }^{2}$, mas também pela facilidade de inserção $e$ de contato com os entrevistados, possibilitando multiplicar as entrevistas através de suas indicações na mesma cidade. Entrevistei cerca de 60 pessoas no período de dois anos (1996-1998) e, ao mesmo tempo realizei observação direta $e$ participante entre as famílias. Elas concederam entrevistas e, de modos diversos, incorporaram minha presença nas suas atividades e nas rotinas da cidade. Desde esse período de campo intensivo, mantenho visitas periódicas. Ao menos uma vez ao ano retorno ao Chuí para reencontrar os entrevistados com os quais iniciei a pesquisa e refletir sobre as mudanças mais recentes na vida dos imigrantes na cidade, aproveitando para conhecer melhor aqueles que interagem diretamente com os imigrantes. O campo tornou-se mais interessante na medida em que, durante estes 10 anos, pude acompanhar eventos e outras modalidades das iniciativas coletivas que versavam sobre a origem "Palestina".

As atividades públicas evidenciavam a presença de duas gerações a partir das famílias migrantes chegadas ao Brasil no

2 As lojas dos comerciantes de origem árabe estão concentradas no lado brasileiro da fronteira. 
final da década de 50 - pais migrantes e filhos brasileiros -, mas também um intenso trânsito de estrangeiros oriundos da Jordânia com visto de permanência de estrangeiro. Na perspectiva de órgãos oficiais de defesa dos direitos humanos, os entrevistados "mais velhos" desta pesquisa seriam de uma "segunda geração" de palestinos que cresceu tendo o Estado de Israel como uma realidade. Migraram para o exterior, primeiro para países do mundo árabe, depois para o Brasil. ${ }^{3}$ Tiveram uma experiência de inserção no novo país, ou seja, aprendizado do português $e$ espanhol e inserção no comércio ambulante ou como sócios de lojas de pequeno porte. No entanto, a maioria de entrevistados desta pesquisa são da terceira geração, filhos desses migrantes já "estabelecidos".

É possível dizer que os "árabes" no Chuí somam ao todo, entre 200 a 500 pessoas em um universo de 3,5 mil habitantes. ${ }^{4}$ No entanto, os dados estatísticos disponíveis são escassos e pouco confiáveis, sujeitos a lutas políticas, muitas vezes superestimando o número de eleitores e moradores no sentido de viabilizar a existência da localidade recém emancipada que conquistou o estatuto de município em $1995 .{ }^{5}$ Há ainda outros motivos para duvidar da precisão dos dados oficiais. Os dados disponíveis no

3 Os órgãos oficiais palestinos e estudiosos consideram que há, atualmente, até uma quarta geração de palestinos desde a criação do Estado de Israel, que corresponderiam aos netos destes "estabelecidos" no Chuí.

4 Conforme o censo do IBGE, o Chuí (Brasil) tinha 3.614 habitantes em 1996. Um levantamento de 1997 feito pelo Departamento de Assistência Social da prefeitura do Chuí registrou 6.564 habitantes. Os dados que estimam a presença de migrantes de origem árabe não são precisos. Os entrevistados que ocupam cargos públicos na cidade estimam em cerca de 200 pessoas de origem árabe que são, de fato, votantes.

5 Parte destes dados sobre estrangeiros residentes no Chuí foi fornecida pela Polícia Federal. Conforme esta fonte, em dezembro de 1999, havia 134 jordanianos e 13 palestinos morando na cidade. Conforme esta mesma fonte, as três cidades no Rio Grande do Sul que concentrariam mais jordanianos seriam, por ordem, Uruguaiana (fronteira com Argentina), Chuí e Livramento (fronteira com o Uruguai). 
Famílias palestinas no extremo sul do Brasil e na diáspora

IBGE sobre o município de Santa Vitória do Palmar, por exemplo, não registram muçulmanos na localidade, embora todos os interlocutores recém-migrados - que deveriam constar neste registro - indicassem que são muçulmanos. Os dados estatísticos tampouco permitem indicar que no comércio predominavam árabes, apesar dessa atividade, a principal da cidade de fronteira, atrair, além de cearenses e paulistas, muitas pessoas oriundas do mundo árabe: egípcios, sírios, sudaneses, libaneses, e... palestinos.

Porém, ao conhecer os comerciantes do local, constata-se que as casas de comércio mais antigas e os maiores supermercados são gerenciados por famílias de origem árabe. As lojas abrem suas portas muito cedo e desde então começam as conversas em voz alta e em árabe, espanhol e português. Alguns comerciantes empregam também os recém-chegados na cidade e no Brasil. Há, portanto, uma presença não-quantificada de árabes que permanecem alguns períodos na localidade e que visitam o Brasil por algumas temporadas como turistas, recebidos pela solidariedade baseada na indicação de pertencer a uma mesma cidade natal, pela origem árabe, ou seja, um domínio comum do idioma árabe.

Nas casas de comércio no "lado brasileiro" da rua internacional há ainda outra peculiaridade. Desde meados dos anos 90 houve uma proliferação de antenas parabólicas que dá para a cidade um aspecto interessante. Muitas destas parabólicas são fixas e permanentemente ligadas na Rede Dubai. Nas localidades próximas é possível ter um leque de canais em idioma árabe que chama a atenção, posto que a oferta não é disponível da mesma forma em todo o Brasil. Assim, televisores dispostos junto ao balcão do comerciante transmitem a programação em árabe para o dono do estabelecimento e para grupos de amigos que, conversando em árabe, se reúnem nas lojas para assistir a televisão. ${ }^{6}$

${ }^{6}$ Em casa, ver a TV aberta ou a cabo em outros canais é mais comum. Na época do trabalho de campo, as famílias acompanhavam as novelas e sabiam o 
Na época em que iniciei meu trabalho de campo, 1996, em plena vigência do Mercosul, as fronteiras pareciam "abandonadas" pelos compradores. Os uruguaios estavam diante de uma moeda brasileira mais forte e com produtos mais caros e, de outra parte, os brasileiros não se destinavam para os free-shops de importados na fronteira, pois o dólar estava muito caro. Ou seja, os imigrantes palestinos que se fixavam na fronteira, como comerciantes no lado brasileiro avaliavam que tinham feito um erro de cálculo sobre as vantagens dessa fronteira, comparando com a experiência relatada por outros patrícios sobre outras fronteiras.

Nos anos seguintes, a atividade de arroz desenvolvida no extremo-sul do Brasil dava indicadores de sua fragilidade. Logo, a atividade predominante reforçava a escassez de dinheiro no mercado local e colocava em relevo a fragilidade da atividade comercial. $\mathrm{O}$ fato é que a permanência desses imigrantes em um comércio em que o dinheiro se tornava algo raro $^{7}$ era motivo de avaliar se iriam se manter na localidade ou não.

Todavia, os cálculos que levam as famílias a reordenar seus lugares de moradia $e$ trabalho não se restringem à esfera econômica. Dependem de outros elementos. Nos anos seguintes, algumas das famílias que entrevistei se mudaram para São Paulo e outras para lugares - eventualmente, no exterior - em que algum irmão acenava com possibilidade de permanência. Em muitos casos, as famílias eram conduzidas por redes de relações que indicavam para onde deslocar a vida comercial - lugares onde teriam respaldo de conhecidos e patrícios.

Com minha permanência prolongada no Chuí foi possível verificar que a "viagem" não era uma prática que ocorrera somente nos anos 80. Encontra-se ainda hoje disponível, na

que o noticiário no Brasil havia comentado sobre um ou outro fato no mundo, fatos que muitas vezes tinham sido noticiados primeiramente pela Dubai.

${ }^{7}$ Lembro que na economia local muito dos grandes negócios são fechados em sacas de arroz. 
Famílias palestinas no extremo sul do Brasil e na diáspora

medida do possível, não só como uma viagem de retorno, ou para peregrinação, mas como "a viagem" de jovens adultos que irão conhecer uma rede de parentes e vizinhos, seja na Palestina, seja em qualquer outra cidade onde residam. No primeiro caso, acabam descobrindo que a terra "de origem" só assume significado através das relações familiares. E, no segundo, descobrem que manter os vínculos familiares leva inevitavelmente a reviver a identidade palestina, recriando de certa forma a própria base territorial. As situações das famílias são variadas, todavia a conexidade das redes de relações entre parentes se mantém revitalizada por promessas de reencontro.

\section{A viagem de retorno: \\ o território que encerra a memória familiar}

Para além de estreitar laços familiares, as viagens à Palestina são claramente uma proposta de retomada do tema da origem disponibilizada pela família. As viagens são uma iniciação que se refere ao aprendizado formal ou informal do idioma árabe especialmente para os filhos de migrantes que casaram com brasileiras. Através das viagens de retorno, alguns "consensos" sobre a família palestina são estabelecidos em momentos de reflexão da experiência direta, através de uma comparação entre "lados" da parentela (o lado brasileiro e o lado árabe) ou por uma inserção em uma parentela na qual o sujeito se percebe como um estrangeiro que tem de se adaptar a esta situação como "sua".

Para os migrantes (os pais, nascidos na Palestina) a viagem é também associada à obrigação como muçulmano de peregrinar ao menos uma vez na vida para Meca. Algumas fotos expostas nas lojas marcavam, com o uso de trajes palestinos, o Rata e suas longas túnicas bordadas, o momento em que a peregrinação foi feita. Era um assunto de conversa de amplo conhecimento do restante da família - esposa e filhos - quando não tinham participado eles mesmos da peregrinação. Por exemplo, El Jundi, uma das lideranças na vida comercial no Chuí e um dos 
fundadores do Clube árabe, levou seu filho Sami, em dezembro de 1983 para Zarka e, 10 anos mais tarde, repetiu a viagem com o outro filho. Na segunda vez, aproveitou a viagem para combinar peregrinação e turismo (além do Oriente Médio, passaram por Moscou). Hoje, Tarik, o filho mais novo, vive na Itália com passaporte italiano (por parte de mãe). Sami, médico, permanece em Chuí e se mantém envolvido com os debates da questão palestina travados nas organizações de palestinos na diáspora.

Até a viagem, Sami dizia não ter nenhuma informação sobre a vida do pai e seus familiares. Este filho de imigrante com uma brasileira lamentava não ter aprendido árabe em casa, embora fosse algo que conhecia pelo lado negativo, pela "pecha de turco" 8 , como referia. Houve "tentativas esporádicas" de ensinar o árabe, mas aparentemente com poucos resultados. Como artefato da cultura palestina, tinha apenas alguns tapetes na parede, "uma que outra peça trabalhada" - coisas mandadas por parentes ou trazidas por um irmão que veio de visita.

(...) Eu não me lembro o quê ele tinha em casa. Mas eram coisas que pra mim não tinham nenhum significado. Não significava nada se meu pai andasse com o rosário na mão, contando continhas, não... não representava muita coisa pra mim. Tinha aquela coisa de que eu ia conhecer a família do meu pai, ia morar no Oriente Médio, mas... era como se aquilo fosse solucionar tudo o que a gente não

\footnotetext{
8 É importante tornar explícito o que envolve a denominação de "turco" como acusação. Em que pese ela ser entendida como uma classificação neutra, atribuída pelo poder público brasileiro no início do século no momento de entrada de árabes oriundos de regiões dominadas pelo Império Otomano, a expressão carrega outras conotações. Durante o trabalho de campo essas conotações foram sendo reveladas na localidade por aqueles que não tinham origem árabe; para estes, tudo o que é vendido em lojas "dos turcos" é visto como uma imitação da moda, um artigo de segunda qualidade, uma falsificação de grifes, vendida a preços mais baixos que as lojas que ditam as regras do bem vestir na localidade - no caso, as lojas situadas em Santa Vitória do Palmar.
} 
Famílias palestinas no extremo sul do Brasil e na diáspora

sabia até então. Então, era a questão do momento de ir, $e$ lá eu ia ficar sabendo de tudo. A coisa era assim.

No Chuí, há famílias de imigrantes que cultivam o idioma árabe como comunicação preferencial com os filhos nascidos no Brasil. O domínio do árabe na vida social da localidade é bastante comum e confere um reconhecimento singular. Mas, em outras famílias, como foi o caso de Sami (de mãe brasileira), trata-se de um aprendizado tardio possibilitado por uma viagem de visita à família. Nesse caso, as viagens não são planejadas para serem curtas. Muitas visam uma matrícula na escola, um ano de residência, uma boa inserção entre parentes e vizinhos. Os pais sabem, por experiência de outros vizinhos, que quanto mais tempo protelarem a viagem de retorno, mais difícil será integrar o jovem na Palestina, nos costumes ou simplesmente falar em árabe, no seu próprio idioma, com seu filho.

Sami permaneceu sete meses na Palestina (dezembro de 1982 a junho 1983) na casa da irmã do pai e sua iniciação na cultura foi processada pelos parentes paternos. Foi uma experiência de muitos estranhamentos e aprendizados não somente da língua árabe:

Sami - (...) E, realmente, eu não tinha muita coisa pra fazer lá. Esse primeiro ano era pra aprender o árabe, porque se eu gostasse, então, no ano seguinte eu iria...(...) [Fui] aprendendo com a família. Eu tinha um tio, um outro primo do meu pai, que era professor, professor daqueles professores, sabe, alfabetizadores, né. Então, eu ia pra casa dele todo o dia. Eu tinha uma aula com ele todos os dias. Não era uma aula, no sentido clássico. (...) Chegava lá na casa dele, eu, acostumado, chegava disposto a ter uma aula, né. Então, ele, bem tranqüilo: "vamos conversar". [Então sentava do lado dele, a gente ficava conversando, tomava um chá.]

Denise - Ele só falava em árabe? 
Denise Fagundes Jardim

Sami - Só em árabe, sempre em árabe. Lá de vez em quando, que eu não entendesse algo assim muito complicado, ele me explicava em inglês. Um inglês que eu sabia mal e porcamente, mas que era o mais próximo do... da minha língua, então ficava um pouco mais fácil. E... então, eu sentava, tomava um chá, comia uma fatia de bolo. E nesse meio tempo, ele ia conversando comigo. Daí a pouco ele mandava eu abrir o caderno, desenhava uma letra e mandava eu repetir, eu tava aprendendo a escrever, o alfabeto e aprendendo a escrever. Então, mandava eu repetir. Aí eu repetia, ele me dava mais um teminha de casa em cima daquela letra e me liberava. Não chegava a ser uma aula. Aí a gente ia sentar... ele me levava pra sentar com os outros velhos pra conversar. Então, eu me sentava com as pessoas com... ele era vizinho do irmão mais velho do meu pai, então, a gente sentava todo mundo na calçada e ficava conversando e tomando chá. Depois eu batia uma bola com os filhos dele na rua e tava...

Entre as famílias pesquisadas, existem aquelas que não realizaram essa viagem, famílias cujos filhos falam um árabe aprendido em casa, considerado dialetal de Ramallah. Isto é mais comum quando pai e mãe são palestinos. Mesmo assim, a viagem está no horizonte como possibilidade de tecer casamentos para os filhos e propiciar outro tipo de escolarização.

Vemos então que a viagem à Palestina passa a cumprir vários objetivos e expectativas simultaneamente: um retorno $e$ uma peregrinação do migrante, um aprendizado formal (ou informal) do idioma e dos costumes árabes para os filhos, o ingresso na vida escolar em árabe e, como veremos mais tarde, a possibilidade de traçar casamentos futuros. Entretanto, tamanho evento também traz certa perturbação.

\section{Negociando costumes: dificuldades de adaptação}

Justamente porque o aprendizado do idioma comporta também uma atitude - um "aprendizado dos costumes" - a 
Famílias palestinas no extremo sul do Brasil e na diáspora

viagem traz a tona uma intensa polêmica familiar sobre o comportamento dos filhos. A maioria destes nasceu no Brasil e cresceu no seio de famílias com modos de vestir, dormir e organizar a cooperação familiar bem distintos dos imaginados para a família árabe. Mesmo assim, nem tudo o que os pais migrantes esperam que os filhos encontrem na Palestina, depois de 20 anos, é tal qual o projetado. Os filhos de palestinos passam a conhecer o vigor $e$ a realidade de certos modelos de família árabe, de modo plural, através de experiências conflitivas em adequar-se ou lidar com códigos diferenciados. Nesse sentido, os problemas encontrados pelos jovens, no decorrer desse "retorno", são muito reveladores.

Sami, por exemplo, encontrou, junto com a dificuldade de aprender a língua, o desafio de conviver com uma família "humilde":

Sami - (...) o que eu não consegui superar foi a limitação do vocabulário. A família... uma família humilde, tanto financeira quanto... quanto socialmente, intelectualmente, então o vocabulário que eu aprendi, que eu desenvolvi neste tempo, se restringia às necessidades do dia-a-dia, nada mais que isso.

Denise - Domésticas.

Sami - Era um vocabulário estritamente doméstico. Um pouquinho mais que eu aprendi assistindo televisão e o resto, realmente. Então, saía de casa, quando tentava manter uma conversa um pouco mais elaborada com alguém, aí aparecia a dificuldade.

Sami refere-se a outros atritos, mais explícitos, que diziam respeito a sua indignação diante do tratamento recebido pelas meninas da casa. A família anfitriã tinha nove filhos - cinco mulheres e quatro homens -, mas eram as mais velhas, duas meninas de 21 e 18 anos, as culpadas de tudo que acontecia de errado em casa. 
Denise Fagundes Jardim

[A mais velha tinha] um noivo... vinha, fazia as visitas dele, e eles não se envolviam muito. Então, o saco de pancadas era a outra, a segunda mais velha, com 18 anos que... que tava estudando, tava terminando o segundo grau, tava no último ano se preparando para uma possível universidade, que ela sonhava com isso, tinha essa aspiração. $\mathrm{E}$, se não fosse ela, estourava na outra menina, eram sempre as culpadas. Não importava quem tivesse feito o quê, as culpadas eram sempre as gurias. (...) E eu cometi o erro de começar a me atravessar nesse tipo de coisa. Não era problema meu, mas eu não tinha muita tolerância com esse tipo de coisa.

Sami comenta que enfrentou, ainda, outro estranhamento na prática religiosa. As pressões para que se tornasse muçulmano $e$ frequentasse a Mesquita eram muitas.

Denise - E qual era o argumento pró, e qual era o teu argumento?

Sami - Não tinha argumento. Não se argumenta sobre isso. Sobre a fé não se argumenta. Tem que ser, porque tu é e ponto. Tu mora na minha casa, tu vive no meu país, tu tem que ser e ponto. Então... até certo ponto eu me dobrei, eu comecei a freqüentar a Mesquita. Até tentei, teve.... caiu justamente um mês de Ramadã enquanto eu tava lá, aí eu fiz jejum um dia, terminei o dia amarelo de fome, desmaiando pelos cantos de hipoglicemia. Aí eles quando viram que realmente eu fiz, mas passei mal, aí pararam de me incomodar.

De forma significativa, se Sami conseguiu resistir à conversão formal, mesmo assim reconhece uma certa afinidade pela participação na Mesquita: "Na primeira vez eu fui meio empurrado, aí eu descobri que a Mesquita era um belo lugar pra se passar o dia".

O que aconteceu com Sami não coincide com a experiência de todos. Certas famílias optam por escolarizar os filhos desde 
Famílias palestinas no extremo sul do Brasil e na diáspora

cedo no árabe e, por conseguinte, na leitura do Corão. Há casos de, na mesma família, irmãos em idade escolar terem competências diversas no idioma e nos "costumes" e descobriremse mais ou menos "ocidentais" no contexto de suas relações na Palestina. Questões de gênero também exercem uma forte influência no processo de aprendizagem.

A experiência de Tânia, por exemplo, envolveu o aprendizado tardio do idioma árabe. Teoricamente, fizera a "mesma" viagem que seus irmãos, estavam juntos na mesma casa, mas ela expressa o significado dessa iniciação de uma outra forma. Tânia lembra, por exemplo, que seu comportamento na Palestina era objeto de discussão entre seus irmãos, primos, todos nascidos no Brasil, que queriam decidir sobre a possibilidade das mulheres saírem "sozinhas" na rua ou não. A decisão era dada na família, mas, no caso, havia um debate acirrado. Seu tio, que estava levando suas próprias filhas, tinha uma "mente aberta". Dizia que elas deviam "ir, conhecer, e trazer". Assim, elas faziam "tudo": iam a "Jerusalém na parte judaica, participavam de campeonato de vôlei, de campeonato de basquete, iam a discotecas, iam a barzinhos". Ele tentou galgar as mesmas conquistas para as sobrinhas, dizendo que eram "brasileiras" $e$ que não deveriam ser tratadas com as mesmas obrigações de uma "árabe", mas os irmãos de Tânia tinham outra opinião, tal como recomendavam os irmãos mais novos:

Esse irmão - que é meu irmão homem mais velho, menor do que eu, mas é o irmão homem mais velho - ele... já investigou e já viu como é que é. Então, muita coisa ele nos proibia. Então não podia sair assim, não podia sair assado. Senta no carro, não pode assim, não pode lá, não pode acolá, não pode nada. Então, né, ele... uma mente assim, como os de lá, naquela época, que mulher não podia fazer nada, isso, aquilo. (...) Então, quer dizer que eu não aproveitei... eu me arrependo de muita coisa (...) eu gostaria de ter conhecido mais, de ter feito mais amizades. 
A aprendizagem dessa menina se processou, portanto, de uma forma coerente com o comportamento feminino do lugar. Constrangida, além do mais, pelo fato que tinha acento pesado, $e$ estranhando o novo ambiente, preferia ficar dentro de casa. Assim, fora apelidada de "a menina que não sai de casa". Depois de oito meses, finalmente decidiu se "defender sozinha":

Eu já sabia falar, mas tinha medo de falar e errar, tinha vergonha mesmo. E a casa lá sempre cheia de visitas, né. Sempre, né, se visitando muito lá, sempre tão se visitando. Então, um dia chegou uma visita... e a minha prima tava comigo na sala e a minha mãe tava fazendo chá, e eu tava falando com eles, mas sempre com a minha prima do lado, eu me sentia mais segura com ela do meu lado.(...) É. Aí ela saiu, propositalmente. Ela saiu e me deixou sozinha, pra ver como é que eu me saía. Né que eu me saí bem. Aí, depois que eu vi que eu me saí bem, eu comecei. (...) Aí eu fazia questão até de sair.

Depois eu recebia muitos elogios, porque eu falava com o árabe (com acento) do Egito. Até mandei uma fita pro meu pai. Meu pai gostou muito, chorou quando recebeu a fita e... e todo mundo dizia que a gente tinha aprendido muito rápido, daí eu vi que idade não ... esse negócio de ir velho pra lá não importa, tu aprende. Se tu tem força de vontade, tu aprende. Claro que a gente não chegou a estudar, a seguir uma carreira, porque eu fui pra lá pra aprender a falar e escrever.

Vemos então que as mulheres também relatam as viagens como um momento de aprendizado do idioma árabe e como uma experiência que reforça laços com a família de orientação e com o tema da "origem". Mas, como no caso dos meninos, ou talvez mais, essa experiência reforça aspectos conflitivos das relações de autoridade na família.

A experiência de Tânia, ao mesmo tempo em que ressalta a importância de gênero na vivência de jovens retornando a Palestina, também nos remete ao aspecto iniciático das viagens 
Famílias palestinas no extremo sul do Brasil e na diáspora

internacionais como forma de organizar e dar um tom pessoal e inalienável ao tema da origem. A viagem de Tânia é imediatamente anterior a sua participação na OLP como militante da Sanaud no Chuí e de seu casamento com um filho de migrantes palestinos residentes em Rio Grande e São Paulo?. Acabou frequentando, junto a outros entrevistados "retornados", as reuniões e eventos promovidos pelo Sanaud. Percebemos, assim, outras possibilidades tecidas na viagem: inclusive o despertar para a militância política.

\section{Família, território e pertencimento}

O "retorno" não significa apenas um diferencial perante os "outros", não-árabes ou não "turcos", no Chuí. Representa uma experiência de alteridade, de estranhamento no seio da família, $e$ uma valorização, como parte da identidade pessoal, da "origem" territorial. No entanto, a própria percepção do território é mediada por parentes que guardam a memória do lugar.

Mais uma vez, o depoimento de Sami é o que nos revela a imbricação de origem, terra e família. Ao falar do ancião com quem adorava passar as tardes na Palestina ("o próprio beduíno, um velhão de barbas, árabe típico de filme"), começa com a afirmação categórica, "A herança é a herança cultural da família", e segue relatando:

Ele era a pessoa que sabia quem era filho de quem, de onde tinha vindo, o que fazia da vida. Como nasceu a família, de onde veio o primeiro, como foi a questão da saída da Palestina, da ocupação israelense, como é que eles vieram, como é que o Fulano se virou. Ele guardava a memória da família. Ele morrendo, eu não sei pra quem isso passou... Ele me passava uma coisa... uma coisa... uma coisa forte, de uma pessoa... que, eu me lembre, foi a única pessoa, até hoje, que eu chorei a morte dela.

9 Em árabe, Sanaud significa voltaremos. 
Faisal, outro filho de mãe brasileira e pai árabe, também demonstra um vínculo emocional enorme com a Palestina. Nascido em Santa Cruz do Sul, mudou para Chuí quando tinha oito anos, onde ficou até sair para morar em Ramallah (Palestina). Dos 16 aos 24 anos morou nos Estado Unidos, só para voltar ao Rio Grande do Sul, onde, sendo filho mais velho, seguiu trabalhando com pai e tio, sócios de comércios. Faisal nos lembra que, numa família como a dele, a origem palestina não é a única:

Eu me considero muito brasileiro, tão brasileiro como qualquer outro brasileiro que está vivendo muitos anos aqui neste país. A minha mãe é brasileira nata, pura, de descendência índia.

Entretanto, de todos os lugares onde já morou, "Os momentos mais felizes da minha vida ... foram na Palestina":

Eu era um estrangeiro e eu me sentia como de casa. Lá eu era de lá, pertencia a lá... hã... o lugar onde eu morei lá, de cultura diferente, de povo diferente, de um modo diferente, mas me tratavam como se eu fosse de lá pra sempre. E eles são muito hospitaleiros, são muito amigáveis, são muito honestos, dedicativos, amigos. O bonito do povo palestino é que não importa onde a gente nasce ou se cria...

É possível pensar as viagens como um momento importante da descoberta da "origem", aprendizado tardio do idioma árabe e da descoberta da peculiaridade de uma "família árabe". O que há de comum entre os diferentes relatos dessa experiência são os processos de reconhecimento da conexão dos sujeitos com os laços de parentesco pela linha paterna, que permitem aos filhos de imigrantes se definirem como palestinos. No entanto, é importante lembrar que esse reconhecimento não ocorre somente através da viagem à Palestina, mas também se processa durante os intermináveis contatos travados pelos integrantes da diáspora espalhados pelo mundo. As entrevistas deixam transparecer que 
Famílias palestinas no extremo sul do Brasil e na diáspora

através das diversas viagens internacionais, não necessariamente para a Palestina, mas também através de relações entre parentes e vizinhos percorrendo itinerários internacionais, houve um processo de aprendizado da "origem" ou, em outras versões, um momento em que a família passa a encarnar a origem.

\section{A diáspora: a família re-cria o território}

Quem fala de "diáspora", mesmo informado pelo modelo das organizações internacionais, dá um sentido mais amplo a esta experiência de diáspora, que não se restringe ao sentido de "retorno" a um território palestino e sim ao significado da "família espalhada", "dispersa" e de seu trânsito condicionado e proporcionado pela mesma. Essa "dispersão" é uma realidade familiar bastante comum e partilhada entre os amigos de origem árabe. No entanto, é justamente a dispersão que dá lugar às viagens e à experiência singular de uma "família árabe", calcada na rede ampla de relações numa mesma geração.

O relato, mais uma vez, de Faisal fornece uma apta ilustração da dispersão de parentes. Lembramos que, na época de nossa entrevista, Faisal era um candidato a herdeiro administrativo das empresas familiares, reconhecido por sua inteligência no trato familiar e uma opinião que fornecia muita segurança aos sobrinhos e demais irmãos e irmãs. Na ausência (na cidade) do pai, a família me indicava Faisal e seu irmão mais novo para falar sobre a família. Estes eram nascidos no Brasil, mas estavam inseridos na vida local e cogitavam a vida políticopartidária no Chuí.

Faisal frisa que "o povo palestino é um povo muito sofrido, é um povo que sempre tá na diáspora, sempre tá fugindo, tá sempre saindo". Ele lembra que a grande maioria de amigos que conheceu na Palestina já não está mais lá. Estão nos Estados Unidos ou outro país. Entretanto, existe um vínculo forte entre eles - um que inclui a noção ampla de parentesco: 
Denise Fagundes Jardim

Lá todo mundo é familiar, né. Um é primo do primo do primo do primo do primo, não sei o que. Então, todo mundo se considera familiar. ...São amigos que eu vou ter pra vida toda. Quando eu vou pros Estados Unidos, visito. Vou, fico na casa deles, parece que a gente se viu ontem, entende?

Durante uma entrevista, Munira (casada com um irmão de Faisal), ao me mostrar as fotos sob o tampo de vidro na mesa do escritório da loja na qual trabalha, também sublinha a impressão de dispersão familiar. Assim, fico sabendo de uma irmã casada que mora no Peru, de outra que casou com o primo e mudou para São Borja, do amigo que foi para Inglaterra, do primo que está atualmente nos Estados Unidos... E a história de Said - um jovem com cerca de 25 anos que, na época de nossa entrevista morava em Chuí, onde administrava uma das lojas de sua família - mostra como a mobilidade geográfica pode separar irmãos desde cedo.

Nós nos encontramos pouco. Muito pouco. Família... A nossa família sempre, faz... desde 84, faz 11,12 anos que... a questão de se ver, e se encontrar, e se reunir... não, a familia se desintegrou completamente. Cada um tá pra lá, tá pra cá. Desde oitenta e... faz 12 anos. E começou isso cedo, eu tinha 15 quando começou essa história. Eu e meu irmão voltamos sozinhos pra Palestina, as minhas irmãs tavam no Brasil. Isso foi a primeira divisão. Tá. Depois de alguns anos a minha irmã foi pra Palestina, depois o meu irmão foi pra Inglaterra, o meu outro irmão foi pra Pelotas, as outras irmãs tavam em Novo Hamburgo, $e$ o pai $e$ a mãe tavam em... Uruguaiana. E eu sozinho na Palestina. Tu imagina. Nós ficamos quatro anos sem se reunir, a família toda. Nos reunimos aqui no Chuí, em 88 , pela primeira vez em quatro anos.

Said explica que estudou em Jerusalém durante muitos anos. A família manteve uma casa e uma tutora em Jerusalém 
Famílias palestinas no extremo sul do Brasil e na diáspora

para os filhos estudarem no exterior. Retornou de Jerusalém com 19 anos e permaneceu no Brasil dois anos e três meses. Depois, foi estudar economia na Inglaterra, pois seu irmão estudava em Londres, fazia o curso de economia, e providenciou os papéis necessários (Sua intenção era ir para os EUA, mas não obteve visto). Como entre outras pessoas de sua geração, essas idas $e$ vindas não são vividas sem problema:

Vinte e cinco vezes já atravessei o oceano. Eu tô morando que nem cigano há vinte anos já, não... não quero mais. $\mathrm{E}$ vou morar mais alguns anos ainda, não adianta, tô vendo já, né. Não adianta, tchê, vou ter que parar um dia. E o dia que eu quero parar, quero parar num lugar que eu pertenço. Se aqui eu sou turco, lá na Palestina eu sou brasileiro [risos]. Pelo menos é um consolo, porque quando eu cheguei na Inglaterra, os caras me perguntaram donde eu era, eu já não sabia mais o que falar. Eu falava pra eles: "eu sou palestino do Brasil", "como?", "bom, eu sou brasileiro. Meu pai é palestino". E os caras me viam com a fisionomia bem diferente, oriente médio, tu fala árabe, como os árabes, e depois eu fazia festa com os brasileiros, isso que eles ficavam apavorados...

Apesar de Said referir com certo pesar à dispersão da família e se queixar do duplo (ou múltiplo) pertencimento, também revela como o constante "ir e vir" cria uma conexidade das relações familiares e de vizinhança a partir do Chuí e que não se encerra na localidade.

No seu relato, Said segue exemplificando algo que Faisal disse: "Se unir, o árabe também só se une quando é enterro ou casamento". Começando com o casamento de um amigo palestino em Chuí, vai lembrando outras ocasiões em que encontrava seus amigos e parentes reunidos. Lembra em particular de um casamento durante sua estadia na Inglaterra, quando vieram "os guris" - amigos de Chuí. 
Denise Fagundes Jardim

Foi em outubro de 1993. Foi uma loucura, era o casamento da... de uma prima dos caras aí, dos amigos meus. Bah, isso aí... tinha um monte de gente da região da Palestina no casamento. Ah, foi demais.

Muitas dessas famílias falam que são "da mesma cidade" na região de Ramallah na Palestina. Esta é uma explicação nativa para seus encontros freqüentes, realizados em festas de casamento e noivados. Além de proporcionar viagens internacionais, as festas de casamento permitem atualizar os laços em redes de relações que não necessariamente se restringem a parentes "lá" $e$ as ampliam para os vizinhos do local que irão visitar no exterior, mesmo que isso tenha um sentido "prático". Assim, esta conexidade extralocal das relações entre filhos de migrantes não se restringe aos laços familiares, mas também inclui a vizinhança no Chuí que compartilha das redes da cidade de Ramallah.

Vemos então que a maioria das viagens tem uma motivação gerada e viabilizada através das relações familiares. Ou seja, nas famílias pesquisadas, as viagens internacionais são planejadas com alguns anos de antecedência. Mesmo assim, a freqüência das viagens poderia levar a crer que viajar para o exterior é algo fácil. Assim, devemos salientar que, ao contrário, há um esforço enorme despendido no planejamento e na viabilidade dessas viagens internacionais, muito caras e muito longas. Planejar as permanências de alguns meses no exterior não é coisa fácil. Diferente de uma viagem turística, o planejamento da viagem tenta aliar vários aspectos: quem os hospedará (quais familiares), quem os receberá no aeroporto, qual o itinerário de visitas a cidades e pessoas, se será uma viagem utilizada para um período de investimento escolar, a pretexto de uma festa de casamento, ou se um investimento religioso, uma peregrinação a Meca, sobrepõe esses vários sentidos. São poucos os migrantes que conseguem viver simultaneamente em dois países, gerenciando dessa forma sua vida profissional (comércio em Chuí ou em outra cidade do Sul), assim como a vida familiar (filhos estudando no exterior em 
Famílias palestinas no extremo sul do Brasil e na diáspora

companhia da mãe). Mas há casos em que esse tipo de arranjo, muito caro, é utilizado.

Por outro lado, a experiência de uma família que transita e se encontra em distintos locais provoca situações que exigem uma reorganização e reforço de uma noção de um estilo peculiar de uma "família árabe", aprendida pela experiência da viagem.

\section{A família árabe: autoridade paterna, organização materna}

Durante as viagens internacionais ocorrem decisões individuais. Os relatos dos filhos que viajaram no início da idade adulta mostram os conflitos quanto à decisão individual de permanência e deslocamento internacional. Revelam, através dos conflitos, que aprenderam um "estilo da família", explicando, ao mesmo tempo, como aderiram a propostas concretas de definição de rumos profissionais e afetivos trazidos pelos parentes $e$, em particular, pelo pai.

Faisal descreve as várias influências familiares nas decisões que o levaram a transitar de um lugar para outro. Foi ainda muito jovem para Palestina: "Não tinha opção, né. Tava.. fui acompanhado pela família". Foi lhe oferecida a opção de ficar lá, mas essa opção tinha certa ressalva. Quem queria continuar na Palestina, tinha que voltar eventualmente para morar no Brasil. Imediatamente depois da Palestina, a irmã recém-casada em Nova Iorque o convenceu a ficar lá. Assim, acabou ficando por um tempo e estudando nos Estados Unidos. A desvantagem dessa "fraternidade", do árabe "bem mais unido", que acaba envolvendo tios, primos e membros ainda mais distantes da família, é uma certa perda de privacidade: "O contra é que todo mundo te conhece um pouquinho demais e todo mundo se mete um pouquinho demais na tua vida [risos]". Mas, certamente, ninguém "se mete" como o pai.

Faisal deixa claro seu respeito pelo zelo paternal: "Um pai, antes de fazer qualquer coisa, ele pensa um milhão de vezes. Pensa nos filhos, né, o que é que vai acontecer...". Ao mesmo 
tempo, deixa entender que os filhos, frente à autoridade paterna, sofrem certos constrangimentos. $\mathrm{O}$ filho pode ter talento musical, por exemplo, mas se achar que o pai está contra - que prefere um filho comerciante - pode abandonar seu desejo e satisfazer o do pai.

Denise - Tu acha que... tu acha que em parte tu fez esse tipo de coisa na tua vida?

Faisal - Eu fiz, eu muito.

Denise - Negociou contigo mesmo...?

Faisal - Negociei muito com meu pai.

Denise - Com o teu pai e contigo mesmo?

Faisal - E comigo mesmo. E... hã... o pai árabe é teu pai pra vida toda. Eu posso ter 70 anos e ele 90 , ele ainda vai me mandar, ainda eu vou ter o mesmo respeito, o mesmo carinho. Respeito é uma coisa que a gente tem muito pelos... pelo lado árabe. Não é que pelo lado brasileiro eu não tenho, com a minha mãe eu tenho muito, mas a minha mãe hoje tu pode dizer que ela é mais arabesca do que brasileira, em costume.

Denise - Ela viveu lá, né?

Faisal - Ela viveu lá, e depois ela toda vida viveu com o meu pai e... o jeito que ela vê a vida, acredita na vida, é muito parecido do jeito que meu pai vê e acredita.

James Clifford (1997), discorrendo sobre o fenômeno imigratório, sugere que as mulheres teriam um papel secundário no fenômeno da diáspora, mulheres não tomam a iniciativa de viajar. Para ele, as mulheres viriam depois dos homens, depois de um período de instalação. $\mathrm{E}$, certamente, essa mesma perspectiva se encontra entre os meus informantes homens, materializada no provérbio árabe "as mulheres voam com os maridos"10. A última

${ }^{10}$ Esta observação generaliza algo que não tem se verificado empiricamente, mas que revela o lugar de escuta privilegiado pelo pesquisador. 
Famílias palestinas no extremo sul do Brasil e na diáspora

vez que ouvi essa expressão foi de um homem que se referia às cinco filhas que estavam na Palestina com seus maridos. No seu caso, também devia se orgulhar imensamente da nora que veio da Palestina acompanhando seu filho para morar em um dos apartamentos acima de sua loja: formada em inglês, dava aulas de árabe para turmas de filhas de patrícios. ${ }^{11}$ Enfim, ela também fez o seu vôo junto ao marido.

Entretanto, no caso dos árabes é difícil saber quando localizamos um "pioneiro". Atrás da história de um imigrante árabe há um contínuo de imigrações que o precederam. E, de forma ainda mais significativa, em sua grande maioria, foram imigrações "tramadas" na parentela com a participação mais ou menos explícita das mulheres. É, portanto, minha impressão que as mulheres não estão vindo "depois". Elas estão tecendo as condições da viagem de seus filhos e filhas. Através dos casamentos, o que parece uma viagem de separação da família de um sujeito de uma parentela de origem é relido como uma nova ligação, uma nova configuração familiar.

As mulheres participam das decisões, exercendo um determinado tipo de agency coerente com seu lugar na família. Imigrar não é uma tarefa simples. Existem pessoas, como Sami, opinando que são as mulheres (casadas, mais velhas) quem mandam em casa:

Isso eu vi em todas as famílias. Quem impõe as regras dentro de casa é a mulher e quem preserva o poder do homem dentro de casa não é ele, é a mulher dele. Ela toma as decisões, ela garante que a coisa seja feita daquele jeito $e$ ela garante que os filhos cumpram e sigam as mesmas regras (...).

\footnotetext{
${ }^{11} \mathrm{Na}$ época de meu trabalho de campo na tese (1996), havia uma enorme dificuldade de encontrar uma professora de árabe para as jovens meninas filhas de imigrantes. Hoje, a professora dá aulas em árabe e esclarecimentos em inglês ajudam a comunicação em sala de aula.
} 
Em todo caso, se sua participação é abertamente reconhecida ou não, as mulheres, atuando dentro de um modelo conhecido sobre atribuições tidas como masculinas e femininas, se ocupam de um determinado circuito transnacional de viagens - o circuito matrimonial - e o tem colocado em movimento, ampliando as possibilidades de "ir e vir".

No caso dos árabes, as mães $e$ as tias organizam e atuam em um circuito de comunicação entre familiares: são reconhecidas como mediadoras para traçar casamentos entre jovens inclusive entre aqueles que vivem em cidades e países distantes. Na aldeia, fazem isso normalmente, já que solteiros(as) não se falam diretamente. A comunicação é indireta e feita através de intermediários que querem "encaminhá-los". Ao mediar a comunicação entre parentelas e o interesse recíproco entre solteiros, elas colocam no horizonte familiar a possibilidade de futuros casamentos, sutilmente direcionando novos itinerários para os jovens.

No Chuí, de modo muito pragmático, as mulheres mantêm as trocas de cartas e fotos circulando nas redes de vizinhos e entre parentes. Noticiam os nascimentos, a colação de grau nas universidades, discorrem sobre os "frutos" das uniões $e$, potencialmente, medem as qualidades morais de outras famílias em detalhes cotidianos, nas festas de noivado e casamento de outras famílias imigrantes ou residentes na Palestina - ou em outros países da América Latina. Fotos, cartas e mensagens por fax são os expedientes indispensáveis de uma comunicação nessa rede de mulheres imigrantes.

Assim, embora o relato da imigração seja uma fala autorizada dos homens (Jardim, 2000), em campo percebi uma intensa troca de informações, fotos e possibilidades de reencontros tecidas pelas mulheres como mães que procuram cônjuges para filhos e filhas ou como tias que participam dessas redes de casamenteiras, planejando novas viagens e deslocamentos familiares. Diariamente, são as mulheres - mães e tias - que se ocupam disso e tentam elaborar os possíveis destinos de seus 
Famílias palestinas no extremo sul do Brasil e na diáspora

filhos, com destaque ao que se passava na unidade doméstica $e$ em relação aos casamentos "na parentela", intermediado por essa rede de interconhecimento.

\section{Um nome próprio árabe no passaporte:} obstáculos ao trânsito internacional

Os filhos de palestinos nascidos na diáspora transitam no mundo como nacionais da sociedade de acolhimento $e$, ao mesmo tempo, potencialmente como nacionais da Palestina pela origem paterna. Para tanto, além de batalhar o direito de ingressar na Palestina, deverão obter papéis, documentos locais que os situem em um Estado-Nação e acumular um capital cultural exigido para viver em outro país. Afinal, o estudo sobre os palestinos mostra um acúmulo de experiências sobre o ato de transitar entre ordenamentos jurídicos de estados-nacionais diversos e das possibilidades de "reunião familiar" do ponto de vista legal.

A obtenção de documentos regulares é algo valorizado pelos imigrantes palestinos. Lembro da família Hussein, em especial da mãe imigrante, Dona Gazale, uma senhora nascida em Ramallah que, ao falar de si e da família, referia à quantidade de passaportes (nove!) que os filhos lhe teriam dado, pois estavam residindo no exterior. Ou seja, a reunião familiar dava entrada a essa possibilidade, mas ela se mantinha no Chuí, ou seja, em sua aldeia. Com prazer semelhante à de avó, que expõe as fotos dos netos em poster no interior da loja, demonstrava seu orgulho das conquistas dos filhos, dizendo que cada um tinha lhe dado um passaporte. Eu não pedi para ver a documentação, um assunto que sempre me pareceu muito delicado. (Algumas vezes os entrevistados abriram a carteira para mostrar que realmente eram palestinos e tinham carteiras registrando o local de nascimento.) Todavia, nos meus cálculos, pensando os "ir e vir" entre as moradias dos filhos, seus passaportes poderiam ser no mínimo 
quatro - Canadá, Estados Unidos, Porto Rico, Argentina, - sem contar o documento palestino e o brasileiro.

Obter documentos da sociedade de acolhida é algo que se conquista ao longo da permanência do imigrante e decorre da parceria com outro patrício que já usufruía da condição de Brasileiro, uma sociedade no comércio ou, por fim, um casamento que legitime sua condição e visto permanente. Os meios de conquista do visto são individuais e dependem das condições da acolhida, do fato de aprender os caminhos legais e de ter intermediários que obtenham tal documentação. Entre meus entrevistados, isso quer dizer ter um amigo de origem árabe que tenha um advogado (filho de patrício). Ou seja, que os mediadores sejam confiáveis e ajudem a documentar-se.

A maioria dos palestinos que conheci no Chuí porta documentação brasileira e não uruguaia. No entanto, cabe lembrar que mesmo quando existem os papéis individualmente, a nacionalidade familiar não é unívoca. Justamente porque portam passaportes de diversas localidades por onde passaram em momentos distintos, nem todos os filhos têm a mesma nacionalidade. Dessa maneira, criam-se preocupações quanto ao livre trânsito internacional $e$, no caso dos filhos de palestinos, cálculos estratégicos para superar os empecilhos legais aos reencontros familiares.

Yasser, por exemplo, nasceu no Brasil, e hoje trabalha com seu pai em lojas diferentes de Chuí. Apesar de ser filho de palestino, possui apenas a cidadania brasileira. Assim, relata-me que no tempo que fez sua escolaridade na Palestina vivia com a mãe e suas irmãs e, diferente delas (que possuíam nacionalidade palestina), podia fazer o caminho mais curto, entrando e saindo pelo aeroporto de Tel Aviv, porque porta unicamente o passaporte brasileiro.

Hoje, Yasser é casado com uma mulher palestina, natural de uma cidade na proximidade de Nablus. Para vir ao Brasil, ela obteve um visto permanente. Atualmente, o filho deste casal tem nove meses e é nascido no Brasil. Yasser pondera que o filho é 
Famílias palestinas no extremo sul do Brasil e na diáspora

brasileiro, mas poderá ser anotado na carteira da esposa como filho de palestino. Para uma próxima viagem, Yasser planeja acompanhar o trajeto feito pela esposa e filho. Ou seja, deverão entrar na Palestina pela Jordânia e seguir por terra até a fronteira, pois ela é palestina e não pode descer no aeroporto de Tel-Aviv. Como o filho deve viajar com sua mãe, Yasser quer acompanhar os dois. Mesmo ela tendo a cidadania brasileira, constará também sua cidadania palestina nos registros de aeroporto $e$ isso a impedirá de aportar pelo aeroporto de Tel Aviv. ${ }^{12}$ Se vierem a registrar o menino no passaporte palestino da esposa, como quer Yasser, ele calcula que o filho terá a possibilidade de viver na Palestina. Entretanto, nesse caso, para ficar ao lado de sua esposa e filho, Yasser teria de entrar como turista brasileiro, e permanecer no país como "ilegal" enquanto espera uma anistia.

A imigração não é exatamente uma livre escolha, ou um cálculo de possibilidades, como sustentam os teóricos das motivações econômicas da imigração. Devemos lembrar que além de uma evasão por motivos políticos, a (im)possibilidade de "retorno" é sempre uma questão presente, porque envolve não apenas uma possibilidade de voltar a viver na Palestina, mas as possibilidades concretas de reencontro com a parentela. Vemos então que há uma série de problemas práticos a equacionar passaportes, vistos de permanência e cidadania a que se referem esses imigrantes - e uma experiência importante a desvendar sobre as imigrações contemporâneas. O estudo da experiência dos palestinos nos permite demonstrar um longo percurso de mudança de países e a capacidade (maior ou menor) de enfrentar as dificuldades, driblando os obstáculos legais em agenciar tais deslocamentos e em negociar sua identidade perante burocracias nacionais e, em especial, as aduanas.

Assim, quando a OLP entrou em contato com o clube árabe no Chuí, nos anos 80, falar da Palestina não era evocar o passado exclusivamente do imigrante, mas evocar um assunto presente

${ }^{12}$ Para a análise de outra situação semelhante, ver Heyman, 1995. 
para a parentela. Compreende-se a facilidade com que a OLP pôde "recrutar", mesmo temporariamente, os filhos de palestinos no Chuí (lembramos que o Chuí figurava como a segunda cidade no Brasil em termos da formação de militantes). Através de atividades propostas pelo representante da OLP - cursos de formação política e um circuito de viagens para congressos nacionais e internacionais (no Brasil e na América Latina) - o jovem familiarizava-se com uma organização que reunia pessoas com experiências - familiares, de viagem, e também de dificuldades aduaneiras - semelhantes aos dele.

Falar de fatos internacionais não era somente um cenário ideológico que relacionava a Organização para a Libertação da Palestina aos entrevistados no Chuí. O tema da "origem" já estava devidamente conhecido. Mais do que um impacto indireto das notícias que vinham através de parabólicas, a importância da identidade palestina se devia, em grande medida, à prática da "viagem", pensada pelos pais, primeiramente, como um possível "retorno" e que, para seus filhos, por outro lado, fora uma forma de re-conhecer o tema da origem como uma experiência pessoal e inalienável.

\section{Considerações finais}

Se, de um lado, a viagem revela e organiza uma experiência de reconhecimento de sua identidade palestina, de outro, como evidenciei aqui, as viagens vêm se perpetuando como um modelo de destino possível para a vida adulta. Resulta que as viagens para aprendizado do árabe, ou dos costumes e para assistir aos casamentos traçados nas parentelas têm ajudado os palestinos a reinterpretar o fenômeno imigratório e dar contornos conhecidos à imigração, tornando-a o empreendimento mais previsível e menos arriscado.

A imigração tem se eternizada em suas redes como um processo possível, tanto por questões econômicas, quanto pelo esforço das famílias em religar e ressemantizar a experiência da 
Famílias palestinas no extremo sul do Brasil e na diáspora

diáspora. A imigração palestina em Chuí tem sido agenciada através das famílias "espalhadas". Além de fornecer uma familiaridade com um "valor" familiar e noções sobre a família árabe, essa expectativa constante de reencontros e novos itinerários tem permitido perpetuar seus deslocamentos. Nos seus esforços de planejar novos encontros através de quadros já conhecidos em sua experiência familiar (de diáspora), tendem a transformar a ruptura em continuidade.

Sayad (1977) alega que a verdade da imigração é a ruptura. Pode-se afirmar que os imigrantes palestinos descritos aqui atuam no sentido contrário, no esforço por religar não exatamente à terra de origem, mas a um amplo repertório de referências culturais e de relações familiares. Para os palestinos de Chuí ou de outras localidades, este novo lugar não se reduz a possibilidade de traçar uma permanência e sim em um campo de possibilidades e um futuro promissor.

\section{Referências bibliográficas}

BHABHA, Homi. O Local da Cultura. Belo Horizonte, Editora da UFMG, 1998.

CLIFORD, James. Diasporas. In: Routes, Travel and Translation in the late Twentieth Century. Cambridge, Massachusetts \& London, Harvard University Press, 1997, pp.244-277. . Itinerários Transculturais. Barcelona, Gedisa, 1997.

Coutin, Susan Bibler. Citizenship, Activim and the State. Cultural logics of belonging and movement. Transnationalism, naturalization, and U.S. Immigrants politics. American Ethnologist, 30 (4), 2003, pp.508526.

DAVIS, Uri. Palestine Refugees at the Crossroad of 1996 permanent status negotiations. Shaml Publications, 1996 (www.shaml.org).

DelVAL, Raymond. Les Musulmans em Amerique Latine et aus Caraibes. Recherches \& Documents. Amerique Latines, L'Harmattan, 1992. 
Denise Fagundes Jardim

GEERTZ, C. Form and Variation in Balinese Village Structure. In: POTTER, DIAZ \& FOSTER. (orgs.) Peasant Society, a Reader. Boston, University of California, Berkeley, 1967.

Heyman, Josiah McC. Putting Power in Anthropology of Bureaucracy. The Immigration and Naturalization Service at the Mexico-U.S. Border. Current Anthropology, vol. 36, n 2, april 1995, pp.261-287.

JARDIM, Denise Fagundes. Palestinos: as redefinições de fronteiras e cidadania. Horizontes Antropológicos, $n^{\circ}$ 19, UFRGS/IFCH/PPGAS, Porto Alegre, 2003, pp.223-246.

Palestinos no Extremo Sul do Brasil: Identidade Étnica e os Mecanismos Sociais de Produção da Etnicidade. Chuí/RS. Tese de doutorado/ PPGAS/UFRJ/MN, 2000.

KHALIDI, Rachid. La Formation de L'identité palestinienne: Les Annés décisives: 1917-1923. Qantara, nº 23, Printemps, 1997, pp.34-37.

MoRRIS, Benny. Apendix1: The Number of Palestinian Refugees. In: The Birth of the Palestinian Refugees Problem. 1947-1949. London, Cambridge University Press, 1987, pp.297-298.

SAYAD, Abdelmalek. Les Trois "Ages" de l'Emigración Algerienne en France. Actes de la Recherche, $\mathrm{n}^{\circ}$ 17, jun 1977, pp.59-79. 